\title{
An Exploration of Organizational Change and Employees' Performance in Nigeria
}

\author{
Danlami Joseph Aduku, John Olatunji Alabi, Juwon Johnson Orugun
}

Department of Business Administration, Kogi State University, Anyigba, Nigeria

e-mail: danlamijosephaduku01@gmail.com

DOI: $10.51865 /$ EITC.2021.02.03

\begin{abstract}
This study focused on Organizational Change (OC) and employees' performance in banks in North Central of Nigeria. The study ascertained the effects of tolerance to change and the activities of fraud, and strategy change, organizational structuring, attitude of employees towards change and organizational culture on the performance of banks employee in North Central of Nigeria. The study adopted survey research design. The population of the study for Benue State is 168 and Kogi State is 202. The sample size of the study was 189. Multistage random sampling technique was adopted. Data were analyzed using Multiple Regression. Findings showed that tolerance to change, activities of fraudsters, organizational structuring, strategy change and organizational culture have effect on the performance of banks employee. Finding shows that complexity, attitude of employees towards change and tolerance to change have significant and negative influence, and that perceived advantage and employee motivation has positive and significant influence on the change acceptance of bank employees. The study concluded that $O C$ is pivot to banking practices. The study recommended that bank leaders should sustain change tolerance level, devise better strategic approach to dealing with fraudsters and their activities; this may facilitate employees' improved performance in North Central of Nigeria.
\end{abstract}

Keywords: organizational change; employees' performance; tolerance to change; organizational culture; organizational structuring.

JEL Classification: M10; M59; L20.

\section{Introduction}

In most cases, Organizational Change (OC) is the antecedent of the dynamism of the banking environment of Nigeria. Planned change is engineered by banks today as a proactive or strategic approach towards the dynamic nature of the banking environment today. In this context according to Liebhart and Lorenzo (2010), decision-makers strive to find some stability in the presence of uncertainty using planned methods of change while being aware of the need for flexibility and agility to leverage emerging change and survive it. Cummings \& Worley (2009) argued that $\mathrm{OC}$ is a reflection of the unknown. This implied that changes that organizations witness are products of the unknown, relative to the dynamic nature of the banking and business environment. In a like-mind, Kimaku (2010) expresses further that the uncertain attached with the dynamic environment is likely to adversely affect employees' competencies, worth, and coping abilities and that organization members do not support change unless compelling reasons 
convince them to do so. Research according to Acas (2014) has shown that employees are expressing how they feel about their job and how hard they work with their managers (who can trigger favourable discretionary behaviour; by demonstrating that they care about how change affects their employees).

Change in business operations occurs often in Nigerian Banks. Muhammad, Gatawa and Kebbi (2013) noted that Nigerian Banking System is witnessing major 'policy and liquidity changes' as a result of increasing globalization; the consequence of this is on the banking operating environment, and it may lead to bank failures. Ojo (2010) added that bank failure in Nigeria is increasingly worrisome and it affects the economy of the country; and that failure may be as a result of the inability of some banks to cope with the change engineered by globalization. Dalati (2008) buttressed that banking sector has been subject of scrutiny of both external and internal forces in many countries.

Several studies (Karanja, 2015; Khosa, Rehman, Asad, Bilal and Hussain, 2015) have been conducted with respect to OC in Nigeria and abroad. Khosa et al. (2015) reported that "OC has a positive significant impact on employee's performance in banking sector of Pakistan" (p. 54). Tefera and Mutambara (2014) believe that employee participation in OC can boost employee motivation. If employees perceive organisational change as something that should be feared, it is likely that their motivation will reduce, and this may be counterproductive to the change process goal (Jones, 2010). The study conducted by Contartesi (2010) found that there is positive relationship between leader communication and employee performance. In addition, Nicolaidis and Katsaros (2011) found there is positive relationship between tolerance to change and employees' performance. Also, Dulger (2009) expressed that the extent of the tolerance and employee commitment toward change has important implications for employees' performance. Ebongkeng (2018) noted that the deficiencies of employee performance will be overcome by effective leadership, communication, tolerance to change, procedural justice and organizational culture. Some of the following effects may occur on employees' performance due to an OC (Georges, 2015). Changing an organization's strategy can change the way the organization operates, altering everything from organizational structure to the daily routines of employees (Neba, 2016).

The main objective of the study was to explore understanding on OC and employees' performance in banks in North Central of Nigeria. The specific objectives of the study were to:

o Ascertain the significant effects of tolerance to change and the activities of fraud on the performance of banks employee in North Central of Nigeria.

o Investigate the influence of strategy change, organizational structuring, attitude of employees towards change and organizational culture on employee performance in the North Central of Nigeria.

This study has few limitations; which are perceived non-disclosure of detailed attitude/behaviour towards changes, intact past records of organizational changes and sample size. The sample size however seems to represent the population well through special focus on respondents with organizational change dexterity. The study was limited to the banking industry.

\section{Literature Review}

\section{Conceptual Review}

There have been varying attempts by different scholars to provide a holistic view of OC. This is sequel to the fact that $\mathrm{OC}$ itself is equivocal. It may be inclined by the angle from which an individual has directed his/her investigation. The conceptual clarification of OC may be made considering: 
o Organizational development: Proactive search and identification of development opportunities (Codreanu, 2010).

o External environmental force: $\mathrm{OC}$ in response to the economic, social, technological and political dynamics of an organization's external environment. In contemporary Nigerian business environment, "performance of Nigerian organizations is predicated on these factors" (Akpoviroro \& Owotutu, 2018: 498).

o Internal environmental force: $\mathrm{OC}$ with respect to employee job design, mission, strategies, policies, organizational structure, operation/process design, organizational culture and product/services. These factors can determine the success or failure of organizations (Kinuu, 2014).

Several definitions provided by different scholars have captured one or more of the elements above. The Table 1 below shows the definitions of OC.

Table 1. Conceptual clarification of "organizational change"

\begin{tabular}{|c|l|l|}
\hline S/N & \multicolumn{1}{|c|}{ Author } & \multicolumn{1}{c|}{ Definition } \\
\hline 1 & Lines (2005) & $\begin{array}{l}\text { OC is 'considered as an intentional change design in the } \\
\text { official structure of the organization, systems, processes } \\
\text { or product market, which is attempting to improve the } \\
\text { achievement of one or more organizational goals'. }\end{array}$ \\
\hline 2 & McNamara (2011) & $\begin{array}{l}\text { OC generally means 'rightsizing, new development and } \\
\text { change in technologies, rescheduling operations and } \\
\text { major partnerships'. }\end{array}$ \\
\hline 3 & Khosa et al. (2015) & $\begin{array}{l}\text { OC involves 'mission changes, strategic changes, } \\
\text { operational changes (including structural change), } \\
\text { technological changes, changing the attitudes and } \\
\text { behaviours of personnel, counter resistance from different } \\
\text { employees of companies and align them to strategic } \\
\text { directions of the organization'. }\end{array}$ \\
\hline 4 & Karanja (2015) & $\begin{array}{l}\text { OC is 'any action or set of actions resulting in a shift in } \\
\text { direction or process that affects the way an organization } \\
\text { works'. }\end{array}$ \\
\hline 6 & Phelik and Ozsoy (2016) & $\begin{array}{l}\text { OC can be defined as 'change in organizational structure, } \\
\text { its systems, employees and relation of between them in a } \\
\text { planned or non-planned way'. }\end{array}$ \\
\hline
\end{tabular}

Source: Authors.

OC looks both at the process in which any organization changes its operational methods, technologies, organizational structure, whole structure, or strategies, as well as what effects these changes have on it. OC is usually re-engineered or accepted in quick reaction to or as a result of external pressure (from global or domestic forces outside the banks) or internal pressures (arising process, operational and structure changes). Ezekiel (2007) expressed that two types of forces exist in managing change process generally; such as "the driving forces that set in motion the change process and the restraining forces that resist the change process in organizations". Daniel (2019: 59) added that "this clearly reveals that one of the major problems confronting managers in managing any type of change is resistance to change". Daniel (2019: 60) stated that:

"Change Management is a process involving unfreezing, moving, and refreezing values, practices, and procedures within organizations. Unfreezing refers to the creation of a perceived discrepancy between the existing and ideal state of an organization that generates a desire for change and lowers people's resistance to change." 
There is need for managers to adopt the most effective approach to mobilize support for and embracement of change in their organization. Resistance to change is as a result of gap in the managerial approach.

The environment of banks in Nigeria constantly calls for change. This understanding made Ojo (2010) to express that the need for a change-oriented approach in their management becomes critical; because many banks failed in the past as a result of the complexity of change. Banks must be reactive to change emanating from uncontrollable forces in the broad environment and as well be proactive enough by initiating change-oriented approach to take advantage of domestic and the global competition. A more proactive viewpoint is that it is triggered by a progressive manager. This is one of the reasons that Systematic Important Banks (SIBs) engage in constant human capital development in Nigeria. The SIBs also engage in proactive approach to change by periodically electing Chief Executive Officer to lead the banks with new ideas and intellect. Banks have strategically taken advantage of engineered change for some reasons apart from being proactive. These are however in tandem with the perspectives of Lewin's Change Management theory.

Based on the perspective of teleological theory (also known as planned change), the rationale behind a 'continuous process of goal-setting, execution, evaluation and restructuring' that permeate the SIBs is to facilitate the retention of their status as the spinal cord of the Nigerian economy. Teleological theory of change states that the actions of the executives of the SIBs are purposive; goal is the final cause for guiding movement of an entity. Van de Ven, \& Poole (1995: 516) stated that "the entity is purposeful and adaptive; by itself or in interaction with others, the entity constructs an envisioned end state, takes action to reach it, and monitors the progress". Lewin's Change Management Model advocates that the essence of managing change (by promoting effective communications and empowering employees) is to initiate best practices to bring about operation effectiveness and efficiency. This implies that a bank that is reactive or proactive to change is conscious of its operations environment. Managing change reflects the technical ground for best practices, and a good fit between the bank staff and banking operations/processes. Failure to take cognisance of this is likely to bring about constant struggle to survive or death in the banking environment. Karnouskos (2015: 12) added that "Lewin's Model deals with overcoming resistance to change and how to sustain change once it is made". Dialectical theory assumes that a bank is like a multi-cultural society which has opposing values (Woods, 2013). When one specific force dominates over others, a new value is created, and the establishment of new goal becomes inevitable. In respect of this, OC is likely to occur. The SIBs are observed to have target for their OC.

Yang, Zhuo and $\mathrm{Yu}$ (2009) asserted that the most popularly known targets of OC include 'vision, strategy, culture, structure, system, operation technology, and leadership style'. Vision indicates what banks want to achieve at the long run (which is expressed in their organizational core value). The core values of these banks are influence by change emanating from the interplay between the external environmental forces. Realistically, many executives are guilty of not revisiting the core value of their banks when OC occurs. On a practical note, the vision of organizations is often reshaped by changes caused by uncontrollable environmental forces. Better way of protecting the vision of the organization is through the development of new strategy or change in the existing strategy.

\section{Methodology}

This study adopted survey research design. This research identified three-in-one aggregation groups of interest. These are banks that are regarded as SIBs (SIBs) in Nigeria. The SIBs are the pillars of Nigerian economy; thus the Central Bank of Nigeria makes no financial or economic policy without reference to them. Meanwhile, two states (Kogi State and Benue State) were the 
study's quantitative attributes (areas of interest). The distribution of SIBs staff across Kogi State and Benue State in the North Central geopolitical zone is stated in the Table 2.

Table 2. Distribution of respondents per state and banks

\begin{tabular}{|c|c|c|c|c|}
\hline State & First Bank of Nigeria & $\begin{array}{c}\text { United Bank for } \\
\text { Africa }\end{array}$ & Zenith Bank & Total \\
\hline Benue & 68 & 50 & 50 & $\mathbf{1 6 8}$ \\
\hline Kogi & 66 & 80 & 56 & $\mathbf{2 0 2}$ \\
\hline Total & $\mathbf{1 3 4}$ & $\mathbf{1 3 0}$ & $\mathbf{1 0 6}$ & $\mathbf{3 7 0}$ \\
\hline
\end{tabular}

Source: Field Survey 2020.

Table 2 shows that there were 68 potential respondents from the First Bank of Nigeria in Benue State and 66 potential respondents from the same bank in Kogi State. Secondly, the table shows that there were 50 potential respondents from the United Bank for Africa in Benue State and 80 potential respondents from the same bank in Kogi State. Lastly, the table shows that there were 50 potential respondents from the Zenith Bank in Benue State and 56 potential respondents from the same bank in Kogi State. Based on the focus of this study, the sub-population of SIBs in the North Central (for Benue State) is 168 potential respondents and the sub-population of SIBs in the North Central (for Kogi State) is 202 potential respondents.

In choosing the sampling size and securing representative responses, the size of the sample was based on statistical estimation theory considering degree of confidence that is expected from this type of research. For this study, given the population for each state (Benue- 168 and Kogi202) in the North Central, the research adopted Sallant and Dillman's (1997) method. The formula is stated below:

$$
N_{s}=\frac{N_{p}(p)(1-p)}{\left(N_{p}-1\right)\left(\frac{B}{c}\right)^{2}+(p)(1-p)}
$$

Where:

Ns = completed sample size required;

$\mathrm{Np}=$ sample population;

$\mathrm{P}=$ proportion expected to answer in a certain way $(50 \%$ or 0.5 is most conservative);

$\mathrm{B}=$ acceptable level of sampling error $(0.05= \pm 5 \% ; 0.03= \pm 3 \%)$;

$\mathrm{C}=\mathrm{Z}$ statistic associated with the confidence interval $(1.645=90 \%$ confidence level; $1.960=95 \%$ confidence level; $2.576=99 \%$ confidence level).

The sample size of the study for each state was 189 . The sub-samples for the focused states were based on the Bowley's Proportional Allocation. This is because the SIBs in Kogi State make the majority, and virtually the sub-sample method allocates $54.5 \%$ to SIBs in Kogi State in terms of computation.

The sub-samples are shown below:

Kogi State $=202(189) / 370=103.1837838=103$

Benue State $=168(189) / 370=85.81621622=86$

For this study, multistage random sampling technique was adopted. We considered multistage sampling with simple random without replacement sampling at the first stage, and with an arbitrary sampling design for further stages.

The selection of the sample unit was based on two specific criteria (such as inclusive criteria and exclusive criteria). The inclusive criteria focused on the categories of individuals that were 
taken for the survey (respondents with sound mind, ability to understand the subject matter, sound health and work experience of at least five years). The exclusive criteria involved the categories of individuals that were excluded for the study. They were employee who were not available at work, sick or ill, have less than five years work experience and so on.

The study used well-structured questionnaire for the survey. The items were measured using 5point Likert scale. To establish the instrument's reliability, the Cronbach Coefficient alpha $(\alpha)$ was used. Technology change $(\alpha=0.797)$, effective leadership $(\alpha=0.743)$, strategy change $(\alpha=$ $0.738)$, organizational structuring $(\alpha=0.936)$ and organizational culture $(\alpha=0.735)$ shows strong reliabilities. Since Zikmund et al. (2010) asserted that the coefficient alpha of 0.70 marks the critical point, then the constructs are considered to have good reliability.

The data generated for the study were analysed using both descriptive and inferential analytical techniques. The analytical techniques that were employed are basically three: Logit Regression, Multiple Regression and correlation matrix. Analyses were done using SPSS statistical package version 20.0.

The model specification was shown below. The general form for the model in the work is given as:

Where:

$$
\mathrm{EP}=\mathrm{a}+\mathrm{b}_{1} \mathrm{TTC}+\mathrm{b}_{2} \mathrm{AOF}+\mathrm{e}
$$

$\mathrm{EP}=$ Dependent variable (employee's performance);

$\mathrm{a}=$ constant;

TTC - tolerance to change and AOF - activities of fraud are independent variables;

$b_{1}$ and $b_{2}=$ regression coefficients which determine the contribution of the independent variables;

$\mathrm{e}=$ residual or stochastic term.

Where:

$$
\mathrm{EP}=\mathrm{a}+\mathrm{b}_{1} \mathrm{SCE}+\mathrm{b}_{2} \mathrm{OSG}+\mathrm{b}_{3} \mathrm{ABP}+\mathrm{b}_{4} \mathrm{AEC}+\mathrm{b}_{5} \mathrm{OCE}+\mathrm{e}
$$

$\mathrm{EP}=$ Dependent variable (employee's performance);

$\mathrm{a}=$ constant;

SCE - strategy change; OSG - organizational structuring, ABP - attitudes and behaviours of personnel, AEC - attitude of employees towards change, OCE - organizational culture are independent variables.

\section{Results and Discussion}

This section focused on the analysis of data gathered relative to OC and employee's performance.

Table 3. Model summary on the effects of tolerance to change and the activities of fraudsters on the performance of banks employee in North Central of Nigeria

\begin{tabular}{|l|c|c|c|c|}
\hline & Model & R Square & Adjusted R Square & $\begin{array}{c}\text { Std. Error of the } \\
\text { Estimate }\end{array}$ \\
\hline \multirow{2}{*}{ Benue } & 1 & .958 & .957 & .24626 \\
\cline { 2 - 5 } State & 2 & .961 & .960 & .23879 \\
\hline \multirow{2}{*}{ Kogi State } & 1 & .344 & .337 & .77911 \\
\cline { 2 - 5 } & 2 & .416 & .403 & .73900 \\
\hline
\end{tabular}

a. Predictors: (Constant), Tolerance to change;

b. Predictors: (Constant), Tolerance to change, Activities of fraudsters.

Source: Field Survey (2020). 
Table 3 shows that the effects of tolerance to change on the performance of banks employee in Benue State (with $\mathrm{R}^{2}=0.958$; Std. Error of the Estimate $=0.24626$ ). The table shows that $95.8 \%$ change in the performance of banks employee in Benue State is explained by tolerance to change. The remaining $4.2 \%$ unexplained variables show that there are other variables that account for variation in the performance of banks employee in Benue State. The Adjusted $\mathrm{R}$ Square (0.957) shows the goodness-of-fit for regression models. However, the $\mathrm{R}^{2}$ value of 0.958 shows that the effect of tolerance to change on the performance of banks employee in Benue State is a strong one. The table also shows the effects of the activities of fraudsters on the performance of banks employee in Benue State (with $\mathrm{R}^{2}=0.961$; Std. Error of the Estimate $=0.23879$ ). $96.1 \%$ change in the performance of banks employee in Benue State is explained by the activities of fraudsters. The remaining 3.9\% unexplained variables show other variables are attached to the variation in the performance of banks employee in Benue State. The Adjusted $\mathrm{R}$ Square $(0.960)$ shows that the regression model has goodness-of-fit. The $\mathrm{R}^{2}$ result indicates that the activities of fraudsters have strong effects on the performance of banks employee in Benue State.

Table 3 shows $\mathrm{R}^{2}$ value of 0.344 and the Std. Error of the Estimate (0.77911) between tolerance to change and the performance of banks employee in Kogi State. The table shows that $34.4 \%$ change in the performance of banks employee in Benue State is explained by tolerance to change. The remaining 65.6\% indicates that wide range of variables (which are not captured in the model) can explain variation in the performance of banks employee in Kogi State. The Adjusted R Square (0.337) shows that the goodness-of-fit for regression models is below average. The simple implication of the $\mathrm{R}^{2}$ value of 0.344 is that tolerance to change has weak effect on the performance of banks employee in Kogi State. The table also shows the effects of the activities of fraudsters on the performance of banks employee in Kogi State (with $R^{2}=0.416$; Std. Error of the Estimate $=0.73900$ ). $41.6 \%$ change in the performance of banks employee in Kogi State is explained by the activities of fraudsters. The remaining $58.4 \%$ unexplained variables show that other variables are connected with the variation in the performance of banks employee in Kogi State. The Adjusted R Square (0.403) shows that the regression model has goodness-of-fit of below average. The $\mathrm{R}^{2}$ result indicates that the activities of fraudsters have weak effects on the performance of banks employee in Kogi State.

Table 4. Coefficients on the effects of tolerance to change and the activities of fraudsters on the performance of banks employee in North Central of Nigeria

\begin{tabular}{|c|c|c|c|c|c|c|c|c|c|c|c|}
\hline & \multirow{3}{*}{ Model } & \multicolumn{5}{|c|}{$\begin{array}{c}\text { Column I } \\
\text { (Benue State) }\end{array}$} & \multicolumn{5}{|c|}{$\begin{array}{c}\text { Column II } \\
\text { (Kogi State) }\end{array}$} \\
\hline & & \multicolumn{2}{|c|}{ Unstd Coe. } & \multirow{2}{*}{$\begin{array}{c}\begin{array}{c}\text { Std } \\
\text { Coe. }\end{array} \\
\text { Beta }\end{array}$} & \multirow{2}{*}{$\mathbf{T}$} & \multirow{2}{*}{ Sig. } & \multicolumn{2}{|c|}{ Unstd Coe. } & \multirow{2}{*}{$\begin{array}{r}\text { Std } \\
\text { Coe. } \\
\text { Beta }\end{array}$} & \multirow{2}{*}{$\mathbf{T}$} & \multirow{2}{*}{ Sig. } \\
\hline & & B & $\begin{array}{l}\text { Std. } \\
\text { Error }\end{array}$ & & & & B & $\begin{array}{l}\text { Std. } \\
\text { Error }\end{array}$ & & & \\
\hline \multirow{2}{*}{1} & (Constant) & .074 & .054 & & 1.367 & .175 & 1.66 & .157 & & 10.58 & .000 \\
\hline & TTC & .982 & .023 & .979 & 42.73 & .000 & .44 & .062 & .586 & 7.02 & .000 \\
\hline \multirow{3}{*}{2} & (Constant) & .078 & .052 & & 1.48 & .143 & 2.30 & .240 & & 9.56 & .000 \\
\hline & TTC & .769 & .089 & .767 & 8.65 & .000 & .69 & .095 & .925 & 7.25 & .000 \\
\hline & AOF & .198 & .080 & .219 & 2.47 & .016 & -.83 & .245 & -.432 & -3.39 & .001 \\
\hline
\end{tabular}

Source: Field Survey (2020).

Table 4 shows that the unstandardized coefficient for tolerance to change is 0.982 . The result shows that $98.2 \%$ increase in tolerance to change will lead to proportional increase in the performance of banks employee in Benue State. The table shows the standardized coefficient for tolerance to change $(\beta=0.979 ; p$-value $=0.01)$. The result shows high positive contribution to the performance of banks employee in Benue State. This is because the standardized coefficient for tolerance to change is positive in the model. The implication of this is that tolerance to change significantly and positively contribute to the performance of banks employee in Benue State. The table also shows that the combination of tolerance to change and activities of 
fraudsters predict the performance of banks employee in Benue State. The inclusion of the activities of fraudsters in the model reduced the strength of tolerance to change. Meanwhile, the two variables are positive. The results shows that tolerance to change has higher unstandardized coefficient (0.769) compared with activities of fraudsters (0.198). The standardized coefficient for activities of fraudsters $(\beta=0.219 ; \mathrm{p}$-value $=0.01)$ shows weak contribution; although the contribution is positive. The implication of this is that activities of fraudsters have $21.9 \%$ positive contribution to the performance of banks employee in Benue State. The contribution is seen to be very significant due to the p-value.

Table 4 also shows the result for unstandardized coefficient for tolerance to change (banks in Kogi State) to be 0.435 . This implies that $43.5 \%$ increase in tolerance to change will bring about $43.5 \%$ increases in the performance of banks employee in Kogi State. The table shows the standardized coefficient for tolerance to change $(\beta=0.586$; $p$-value $=0.01)$. The result shows average positive contribution to the performance of banks employee in Kogi State. This is based on the fact that the standardized coefficient for tolerance to change is positive in the model. The implication of this is that tolerance to change significantly and positively contribute to the performance of banks employee in Kogi State. Interestingly, the inclusion of activities of fraudsters in the model led into increased predictive power of tolerance to change. For instance, the unstandardized coefficient $(0.686)$ for tolerance to change rose against the previous 0.435 . This implies that the awareness of persistent activities of fraudsters have muscled tolerance to change by employees. However, the unstandardized coefficient for activities of fraudsters (0.832 ) shows that $83.2 \%$ reduction in the activities of fraudsters will lead to about $83.2 \%$ improvement in the performance of banks employee in Kogi State. The standardized coefficient for activities of fraudsters $(\beta=-0.432 ; p$-value $=0.01)$ shows weak contribution; although the contribution is negative. The implication of this is that activities of fraudsters have $43.2 \%$ negative contribution to the performance of banks employee in Kogi State. The contribution is seen to be very significant due to the p-value.

Table 5. Model Summary on the effects of strategy change, organizational structuring, attitude of employees towards change and organizational culture on banks' employee performance in North Central of Nigeria

\begin{tabular}{|l|c|c|c|c|}
\hline & Model & R Square & Adjusted R Square & Std. Error of the Estimate \\
\hline \multirow{3}{*}{$\begin{array}{l}\text { Benue } \\
\text { State }\end{array}$} & 1 & .891 & .890 & .36986 \\
\cline { 2 - 5 } & 2 & .932 & .931 & .29356 \\
\cline { 2 - 5 } & 3 & .945 & .943 & .26556 \\
\cline { 2 - 5 } & 4 & .951 & .949 & .25278 \\
\hline \multirow{3}{*}{$\begin{array}{l}\text { Kogi } \\
\text { State }\end{array}$} & 1 & .083 & .073 & 1.04450 \\
\cline { 2 - 5 } & 2 & .213 & .196 & .97271 \\
\cline { 2 - 5 } & 3 & .321 & .298 & .90877 \\
\hline
\end{tabular}

a. Predictors: (Constant), Organizational structuring;

b. Predictors: (Constant), Organizational structuring, Strategy change;

c. Predictors: (Constant), Organizational structuring, Strategy change, Organizational culture;

d. Predictors: (Constant), Organizational structuring, Strategy change, Organizational culture, Attitude of employees towards change.

Source: Field Survey (2020).

Table 5 shows the effects of strategy change, organizational structuring, attitude of employees towards change and organizational culture on banks' employee performance in North Central of Nigeria. The table shows that the effects of organizational structuring on the performance of banks employee in Benue State (with $\mathrm{R}^{2}=0.891$; Std. Error of the Estimate $=0.36986$ ). This means that $89.1 \%$ change in the performance of banks employee in Benue State is explained by organizational structuring. The remaining $10.9 \%$ unexplained variables show that there are other variables that account for variation in the performance of banks employee in Benue State. The Adjusted R Square (0.890) shows the goodness-of-fit for the regression models. The $\mathrm{R}^{2}$ value of 
0.891 shows that organizational structuring has strong effect on the performance of banks employee in Benue State.

Table 5 also shows the effects of strategy change on the performance of banks employee in Benue State (with $\mathrm{R}^{2}=0.932$; Std. Error of the Estimate $=0.29356$ ). Thus, $93.2 \%$ change in the performance of banks employee in Benue State is explained by strategy change. The remaining $6.8 \%$ unexplained variables show that other variables account for the variation in the performance of banks employee in Benue State. The Adjusted R Square (0.931) shows that the regression model has goodness-of-fit. The $\mathrm{R}^{2}$ result indicates that strategy change has strong effects on the performance of banks employee in Benue State.

Based on the effect of organizational culture, the result shows the $\mathrm{R}^{2}$ value to be 0.945 and the Std. Error of the Estimate to be 0.26556 . The result in the table shows that $94.5 \%$ change in the performance of banks employee in Benue State is explained by organizational culture. The remaining 5.5\% indicates that a range of variables (which are not captured in the model) can explain variation in the performance of banks employee in Benue State. The Adjusted R Square (0.943) shows that the goodness-of-fit for the regression models is appreciable. The $\mathrm{R}^{2}$ value of 0.945 is that organizational culture has very strong effect on the performance of banks employee in Benue State.

Table 5 also shows the effects of the attitude of employees towards change on their performance in Benue State (with $\mathrm{R}^{2}=0.951$; Std. Error of the Estimate $=0.25278$ ). $95.1 \%$ change in the performance of banks employee in Benue State is explained by the attitude of the employees towards change. The remaining $4.9 \%$ unexplained variables show that other variables are connected with the variation in the performance of banks employee in Benue State. The Adjusted R Square (0.949) shows that the regression model has strong goodness-of-fit. The $\mathrm{R}^{2}$ result indicates that the attitude of the employees towards change has strong effect on their performance in Benue State.

Table 5 shows the effects of organizational structuring on the performance of banks employee in Kogi State (with $\mathrm{R}^{2}=0.083$; Std. Error of the Estimate $=1.04450$ ). This means that $8.3 \%$ change in the performance of banks employee in Kogi State is explained by organizational structuring. The remaining $91.7 \%$ unexplained variables show that there are good numbers of variables that account for variation in the performance of banks employee in Kogi State. The Adjusted R Square $(0.073)$ shows a very low goodness-of-fit for the regression models. The $\mathrm{R}^{2}$ value of 0.083 shows that organizational structuring has very weak effect on the performance of banks employee in Kogi State.

Table 5 also shows the effects of strategy change on the performance of banks employee in Kogi State (with $\mathrm{R}^{2}=0.213$; Std. Error of the Estimate $=0.97271$ ). Thus, $21.3 \%$ change in the performance of banks employee in Kogi State is explained by strategy change. The remaining $78.7 \%$ unexplained variables show that there are other wide ranges of variables that account for the variation in the performance of banks employee in Kogi State. The Adjusted R Square $(0.196)$ shows that the regression model has a weak goodness-of-fit. The $\mathrm{R}^{2}$ result shows that strategy change has very weak effects on the performance of banks employee in Kogi State.

In Kogi State, the effect of organizational culture on the performance of banks employee shows $\mathrm{R}^{2}$ value of 0.321 with Standard Error of the Estimate of 0.90877. The result in the table shows that $32.1 \%$ change in the performance of banks employee in Kogi State is explained by organizational culture. The remaining $67.9 \%$ shows that a number of variables are not captured in the model, and the variables may explain well the variation in the performance of banks employee in Kogi State. The Adjusted R Square (0.298) shows low goodness-of-fit for the regression models. The result $\left(\mathrm{R}^{2}\right.$ value of 0.321$)$ shows that organizational culture has weak effect on the performance of banks employee in Kogi State. 
Table 5 shows the effects of the attitude of employees towards change on their performance in Kogi State (with $\mathrm{R}^{2}=0.361$; Std. Error of the Estimate $=0.88640$ ). This implies that $36.1 \%$ change in the performance of banks employee in Kogi State is explained by the attitude of the employees towards change. The remaining $63.9 \%$ unexplained variables show that other variables are connected with the variation in the performance of banks employee in Kogi State. The Adjusted R Square (0.333) shows that the regression model has weak goodness-of-fit. The $\mathrm{R}^{2}$ result shows that the attitude of the employees towards change has weak effect on their performance in Kogi State.

Table 6. Coefficients on the effects of strategy change, organizational structuring, attitude of employees towards change and organizational culture on banks' employee performance in North Central of Nigeria

\begin{tabular}{|c|c|c|c|c|c|c|c|c|c|c|c|}
\hline & \multirow{2}{*}{ Model } & \multicolumn{2}{|c|}{ Unstd Coe. } & \multirow{2}{*}{$\begin{array}{c}\begin{array}{c}\text { Std } \\
\text { Coe. }\end{array} \\
\text { Beta }\end{array}$} & \multirow{2}{*}{$\mathbf{T}$} & \multirow{2}{*}{ Sig. } & \multicolumn{2}{|c|}{ Unstd Coe. } & \multirow{2}{*}{$\begin{array}{c}\begin{array}{c}\text { Std } \\
\text { Coe. }\end{array} \\
\text { Beta }\end{array}$} & \multirow{2}{*}{$\mathbf{t}$} & \multirow{2}{*}{ Sig. } \\
\hline & & B & $\begin{array}{c}\text { Std. } \\
\text { Error }\end{array}$ & & & & B & $\begin{array}{c}\text { Std. } \\
\text { Error }\end{array}$ & & & \\
\hline 1 & OSG & 1.023 & .040 & .944 & 25.615 & .000 & -.265 & .091 & -.288 & -2.917 & .004 \\
\hline \multirow[b]{2}{*}{2} & (Constant) & -.101 & .070 & & -1.437 & .155 & 2.883 & .224 & & 12.848 & .000 \\
\hline & OSG & .585 & .071 & .540 & 8.279 & .000 & -.520 & .107 & -.564 & -4.872 & .000 \\
\hline \multirow{4}{*}{3} & (Constant) & -.160 & .065 & & -2.462 & .016 & 2.165 & .282 & & 7.685 & .000 \\
\hline & OSG & .500 & .067 & .461 & 7.461 & .000 & -.435 & .102 & -.472 & -4.258 & .000 \\
\hline & SCE & .329 & .057 & .364 & 5.822 & .000 & .269 & .091 & .334 & 2.959 & .004 \\
\hline & OCE & .157 & .037 & .199 & 4.305 & .000 & .364 & .095 & .342 & 24 & .000 \\
\hline \multirow{2}{*}{4} & (Constant) & -.045 & .073 & & -.621 & .537 & 2.318 & .282 & & 8.215 & .000 \\
\hline & OSG & .539 & .065 & .497 & 8.284 & .000 & -.495 & .103 & -.538 & -4.821 & .000 \\
\hline
\end{tabular}

Source: Field Survey (2020).

Table 6 shows the coefficients on the effects of strategy change, organizational structuring, attitude of employees towards change and organizational culture on banks' employee performance in North Central of Nigeria. The result in the table reveals that the unstandardized coefficient for organizational structuring is 1.023 . The result shows that $102.3 \%$ change in organizational structuring will lead to proportional change in the performance of banks employee in Benue State. The table shows the standardized coefficient for organizational structuring $(\beta=0.944 ; p$-value $=0.01)$. The result shows very high positive contribution to the performance of banks employee in Benue State. This is because the standardized coefficient for organizational structuring is positive and above $50 \%$ in the model. This implies that organizational structuring significantly and positively contributes to the performance of banks employee in Benue State.

Table 6 also shows that the inclusion of strategy change in the model made the predictive power and contribution of organizational structuring towards the performance of banks employee (that is, unstandardized coefficient from 1.023 to 0.585 ; standardized coefficient from 0.944 to .540 ) to reduce. The unstandardized coefficient for strategy change is 0.409 . The result shows that $40.9 \%$ change in strategy will bring about proportional change in the performance of banks employee in Benue State. The table shows the standardized coefficient for strategy change ( $\beta=$ $0.452 ; \mathrm{p}$-value $=0.01$ ). The result shows weak positive contribution to the performance of banks employee in Benue State. The implication of this is that strategy change has $45.2 \%$ positive contribution to the performance of banks employee in Benue State. The contribution is seen to be very significant due to the p-value.

Table 6 shows that the inclusion of organizational culture in the model also made the predictive power and contribution of strategy change towards the performance of banks employee (that is, unstandardized coefficient from 0.409 to 0.329 ; standardized coefficient from 0.452 to 0.364 ) to reduce. The unstandardized coefficient for organizational culture is 0.157 . The result shows that 
$15.7 \%$ change in organizational culture will bring about proportional change in the performance of banks employee in Benue State. The table shows the standardized coefficient for organizational culture $(\beta=0.199 ; p$-value $=0.01)$. The result shows very weak positive contribution to the performance of banks employee in Benue State. The implication of this is that organizational culture has $19.9 \%$ positive contribution to the performance of banks employee in Benue State. The contribution is seen to be very significant due to the p-value.

Table 6 shows that the inclusion of attitude of employees towards change in the model also made the predictive power and contribution of organizational culture towards the performance of banks employee (that is, unstandardized coefficient from 0.157 to 0.225 ; standardized coefficient from 0.199 to 0.284 ) to increase. The unstandardized coefficient for organizational culture is -0.106 . The result shows that $10.6 \%$ change in attitude of employees towards change will bring about inverse change in the performance of banks employee in Benue State. The table shows the standardized coefficient for attitude of employees towards change $(\beta=-0.101$; $p$ value $=0.01)$. The result shows very weak negative contribution to the performance of banks employee in Benue State. The implication of this is that attitude of employees towards change has $10.1 \%$ negative contribution to the performance of banks employee in Benue State. The contribution is seen to be very significant due to the p-value.

Table 6 shows that the unstandardized coefficient for organizational structuring is -0.265 . The result shows that $26.5 \%$ change in organizational structuring will lead to inverse proportional change in the performance of banks employee in Kogi State. The table shows the standardized coefficient for organizational structuring $(\beta=-0.288$; $p$-value $=0.01)$. The result shows very low negative contribution to the performance of banks employee in Kogi State. The standardized coefficient for organizational structuring is negative and below $50 \%$ in the model. This implies that organizational structuring significantly and negatively contributes to the performance of banks employee in Kogi State.

Table 6 also shows that the inclusion of strategy change in the model made the predictive power and contribution of organizational structuring towards the performance of banks employee (that is, unstandardized coefficient from -0.265 to -0.520 ; standardized coefficient from -0.288 to 0.564 ) to increase. The unstandardized coefficient for strategy change is 0.366 . The result shows that $36.6 \%$ change in strategy will bring about proportional change in the performance of banks employee in Kogi State. The table shows the standardized coefficient for strategy change ( $\beta=$ 0.454 ; $\mathrm{p}$-value $=0.01)$. The result shows positive contribution to the performance of banks employee in Kogi State. The implication of this is that strategy change has $45.4 \%$ positive contribution to the performance of banks employee in Kogi State. Meanwhile, the contribution appears to be significant based on the fact that the p-value is equal to 0.01 .

Table 6 shows that the inclusion of organizational culture in the model also made the predictive power and contribution of strategy change towards the performance of banks employee (that is, unstandardized coefficient from 0.366 to 0.269 ; standardized coefficient from 0.454 to 0.342 ) to reduce. The unstandardized coefficient for organizational culture is 0.364 . The result shows that $36.4 \%$ change in organizational culture will bring about proportional change in the performance of banks employee in Kogi State. The table shows the standardized coefficient for organizational culture $(\beta=0.342 ; p$-value $=0.01)$. The result shows very weak positive contribution to the performance of banks employee in Kogi State. The implication of this is that organizational culture has $34.2 \%$ positive contribution to the performance of banks employee in Kogi State. The contribution is seen to be very significant due to the $p$-value.

Table 6 shows that the inclusion of attitude of employees towards change in the model also made the predictive power and contribution of organizational culture towards the performance of banks employee (that is, unstandardized coefficient from 0.364 to 0.079 ; standardized coefficient from 0.342 to 0.074 ) to decrease. The unstandardized coefficient for attitude of employees towards change is 0.320 . The result shows that $32.0 \%$ change in attitude of 
employees towards change will bring about positive change in the performance of banks employee in Kogi State. The table shows the standardized coefficient for attitude of employees towards change $(\beta=0.374$; $p$-value $=0.01)$. The result shows weak positive contribution to the performance of banks employee in Kogi State. The implication of this is that attitude of employees towards change has $37.4 \%$ positive contribution to the performance of banks employee in Kogi State. The contribution is deduced very significant due to the p-value.

\section{Discussion of Findings}

Findings show that tolerance to change has strong effect on the performance of banks employee in Benue State, and has weak effect on the performance of banks employee in Kogi State. The implication of this is that there may be high tolerable level of change in Benue State compared with banks in Kogi State. The interpretation of this is that high tolerable level of change has been translating into increasing performance of banks employee in Benue State, and that low tolerable level of change has been translating into low performance of banks employee in Kogi State. This aligns with the finding of studies (Nicolaidis and Katsaros; 2011; Khosa et al., 2015) that a positive relationship exists between tolerance to change and employees' performance. In fact, the finding of this study supports the assertion of authors (Dulger, 2009; Ebongkeng, 2018) that tolerance to change has great implication on employees' performance. It was also empirically proven that the activities of fraudsters have strong effect on the performance of banks employee in Benue State; and that activities of fraudsters have weak effect on the performance of banks employee in Kogi State. Increase in the activities of fraudsters has been found to have positive linear relationship with the performance of banks employee in Benue State. The result shows that increase in activities of fraudsters can make performance of banks employee in Benue State to increase by $19.8 \%$. This implies that there are other factors which account for the high level of performance of banks employee in Benue State. The continuous threating activities of fraudsters may have distracted employees' commitment to outstanding performance in Benue State. On the contrary, empirical investigation proves that increase in the activities of fraudsters has been found to have negative linear relationship with the performance of banks employee in Kogi State. The result shows that increase in activities of fraudsters can make performance of banks employee in Kogi State to decrease by $83.2 \%$. The inverse effect of the activities of fraudsters on the performance of banks employee in Kogi State is strong and significant one. This implies that continuous threating activities of fraudsters will continue to distract employees' commitment to outstanding performance in Kogi State. The contribution of tolerance to change to the performance of banks employee in both Benue and Kogi States is strong and positive. Most importantly, the contribution is significant. Activities of fraudsters have $21.9 \%$ positive contribution to the performance of banks employee in Benue State; but have $43.2 \%$ negative contribution to the performance of banks employee in Kogi State. The contributions are found significant.

Finding shows that organizational structuring has strong effects on the performance of banks employee in Benue State. Finding revealed that the effects of organizational structuring on the performance of banks employee in Kogi State are a very weak one. This implies that it is better to implement organizational structuring in banks in Benue State. The implementation of organizational structuring only has weak significant effect on bank employees in Kogi State. The linear relationship shows that $102.3 \%$ change in organizational structuring will lead to proportional change in the performance of banks employee in Benue State. Meanwhile, it was found that organizational structuring has high positive and significant contribution to the performance of banks employee in Benue State. This finding supports the finding of Methode et al. (2019) that structural change significantly affects employee performance. Finding also shows that $26.5 \%$ change in organizational structuring will lead to inverse proportional change in the performance of banks employee in Kogi State. This implies that there is a negative linear relationship between organizational structuring and the performance of banks employees in Kogi State. It was empirically proven that organizational structuring significantly and negatively 
contributes to the performance of banks employee in Kogi State. This may imply that the initiation of organizational structuring often lower the morale and performance of bank employees in Kogi State. This refutes the finding of Wanza and Nkuraru (2016) that organizational structure positively influences employees' performance.

Finding show that strategy change has strong significant effect on the performance of banks employee in Benue State. Strategy change was also found to have very weak effect on the performance of banks employee in Kogi State. The result of the linear relationship shows that $40.9 \%$ change in strategy will bring about proportional change in the performance of banks employee in Benue State. This implies that there is positive linear relationship between strategy change and the performance of banks employee in Benue State. Finding further shows that the contribution of strategy change to the performance of banks employee in Benue State is weak but positive. The result shows that strategy change has only $45.2 \%$ positive significant contribution to the performance of banks employee in Benue State. The linear relationship between strategy change and the performance of banks employee in Kogi State is positive. Empirical investigation shows that $36.6 \%$ change in strategy will bring about proportional change in the performance of banks employee in Kogi State. Meanwhile, result shows that the contribution of strategy change to the performance of banks employee in Kogi State is weak but positive. The contribution is significant.

Finding shows that organizational culture has very strong effect on the performance of banks employee in Benue State. This aligns with the finding of Nwakoby, Okoye and Anugwu (2019) that organizational culture has positive effect on employee performance in deposit money banks in Enugu State. It was found that organizational culture has weak effect on the performance of banks employee in Kogi State. The linear relationship between organizational culture and the performance of banks employee in Kogi State is weak but positive. The empirical investigation proves that $15.7 \%$ change in organizational culture will bring about proportional change in the performance of banks employee in Benue State. The empirical investigation also proves that the contribution of organizational culture to the performance of banks employee in Benue State is very weak but positive. The meaning of the result is that organizational culture significantly and positively contributes to the performance of banks employee in Benue State by $19.9 \%$. Finding also shows that $36.4 \%$ change in organizational culture will bring about proportional change in the performance of banks employee in Kogi State. It was proven that the contribution of organizational culture to the performance of banks employee in Kogi State is a weak but positive one. From the result, organizational culture has 34.2\% significant positive contribution to the performance of banks employee in Kogi State.

Finding shows that attitude of the employees towards change has strong effect on their performance in Benue State. It was also found that the attitude of the employees towards change has weak effect on their performance in Kogi State. The attitude of the employees towards change has negative linear relationship with the performance of banks employee in Benue State. The empirical result proves that $10.6 \%$ change in attitude of employees towards change will bring about inverse change in the performance of banks employee in Benue State. This is an indication that the attitude of the employees towards change is unfavourable to banks on a general note. Empirically, it was proven that attitude of employees towards change has $10.1 \%$ negative contribution to the performance of banks employee in Benue State. This may mean that the pattern of employees' attitude towards change has contributed to the performance of the banks employee negatively in Benue State. However, the contribution is significant. The empirical result also shows that $32.0 \%$ change in attitude of employees towards change will bring about positive change in the performance of banks employee in Kogi State. This may also imply that the attitude of employees towards change in banks is appreciable in Kogi State. Managers should be able to predict the performance of their employees when certain appreciable attitude towards change is exhibited by the bank employees. Finding further shows 
that the contribution of attitude towards change is weak. The empirical result shows that attitude towards change contributes positively to the performance of banks employee in Kogi State.

\section{Conclusions}

OC has effects on the performance of bank employees. Empirical result affirms that tolerance to change has effect on the performance of banks employee. If employees have high level of tolerance to change, there is possibility that their performance will improve. What matters to achieving desirable change outcome is the employees' tolerance to change. Also, the activities of fraudsters stimulate OC, and these affect the performance of bank employees. Empirical verification proves that the activities of fraudsters have strong effect on the performance of banks employee in Benue State; and that activities of fraudsters have weak effect on the performance of banks employee in Kogi State. Banks vary in their approaches to preventing the activities of fraudsters. In fact, bank leaders play pivot roles in curbing or preventing the activities of fraudsters in their state or region. If strategies are not adopted to prevent the activities of fraudsters, the performance of employees is likely to dwindle.

Organizational structuring, strategy change, organizational culture and attitude towards change are considered to be shaping OC. Empirical evidence provides that organizational structuring has strong effects on the performance of banks employee in Benue State. On the other hand, the effect of organizational structuring on the performance of banks employee in Kogi State is weak. The variation in the effects by states is subject to organizational structuring acceptance by employees and the ability of bank leaders to implement it. Also, strategy change was also proven to have strong significant effect on the performance of banks employee in Benue State. The result seems to be different considering its effect on the performance of banks employee in Kogi State. It was empirically affirmed that strategy change has very weak effect on the performance of banks employee in Kogi State. In addition, the empirical verification confirms that organizational culture has very strong effect on the performance of banks employee in Benue State, but has weak effect on the performance of banks employee in Kogi State. The variation in the finding may be subject to a number of mediating factors which are not investigated in the course of the study. The attitude of the employees towards change was empirically proven to have strong effect on their performance in Benue State, but has weak effect on their performance in Kogi State.

\section{Recommendations}

Based on the findings of the study, the following recommendations were made that:

o Bank leaders should sustain change tolerance level in Benue State; as it contributes to improved performance of their employees. In Kogi State, bank leaders should stimulate or influence increased change tolerance level such that the performance of their employee can improve. Bank leaders should also devise better strategic approach to dealing with fraudsters and their activities; this may facilitated employees' improved performance in North Central of Nigeria.

o Bank leaders and policy makers should focus more on the choice of organizational structure design, strategy change and organizational culture. Bank leaders can maintain their organizational structure design, strategy change and organizational culture in order to sustain improved performance of their employees in Benue State. Bank leaders should embrace improved strategy change, attitude of the employees towards change and organizational culture so as to improve the performance of their employee in Kogi State. Less attention may be given to organizational structure to facilitate improved performance 
of their employees. Also, bank leaders should work on the attitude of their employees towards change in Benue State.

\section{References}

1. Acas (2014). How to manage change. Retrieved on 25/06/2019 from http://m.acas.org.uk/media/pdf/q/q/Acas-How-to-manage-change-advisory-booklet.pdf

2. Akpoviroro, K.S. \& Owotutu, S.O. (2018). Impact of external business environment on organizational performance. International Journal of Advance Research and Innovative Ideas in Education. 4(3), 498- 505.

3. Codreanu, A. (2010). OC: A Matter of Individual and Group Behavior Transformation. Journal of Defense Resources Management. 1(1), 49-56.

4. Contartesi, R.A. (2010). School climate: A correlational analysis of superintendent leadership communication and employee performance. PhD Dissertation: University of Phoenix, 1-8.

5. Cummings, T.G. and Worley, C.G. (2009). Organisation Development and Change, Katalog BPS. doi: 10.1007/s13398-014-0173-7.2.

6. Dalati, S. (2008). The Relationship between Leadership, Organisational Culture and Job Satisfaction: Empirical Evidence from Retail Banking Industry in Wales. PhD Dissertation: Bangor University.

7. Daniel, C.O. (2019). Effects of Change Management on the Performance of Firms in Nigeria. International Journal of Advances in Scientific Research and Engineering. 5(1), 59-64. DOI: 10.31695/IJASRE.2019.33065.

8. Dulger, M. (2009). Human side of change: A conceptual model. Journal of Economics, 3(2), 1-28.

9. Ebongkeng, H. (2018). Organzational Change And Performance: Case study of African Financial Company. Thesis: Centria University of Applied Sciences.

10. Ezekiel, O. (2007). Change Management in Process Change, Information Systems Control Journal, 20(3), 1-10.

11. Georges, F. T. (2015). Organizational Behavior. In: H. Ebongkeng (eds). OC And Performance: Case study of African Financial Company. Thesis: Centria University of Applied Sciences.

12. Jones, G.R. (2010). Organizational theory, design and change, New Jersey: Pearson Education Ltd.

13. Karanja, A.W. (2015). OC and Employee Performance: A Case on the Postal Corporation of Kenya. European Journal of Business and Management. 7(11), 232-241.

14. Karnouskos, S. (2015). Effective Change Management in Modern Enterprises. Degree Project: Linnaeus University.

15. Khosa, Z.A., Rehman, Z.U., Asad, A., Bilal, M.A. and Hussain, N. (2015). The Impact of OC on the Employee's Performance in the Banking Sector of Pakistan. IOSR Journal of Business and Management. 17(3), 54-61. DOI: 10.9790/487X-17325461.

16. Kimaku, P.M. (2010). Change Management Practices Adopted By Barclays Bank Of Kenya Limited. PhD Dissertation: University Of Nairobi.

17. Kinnu, D. (2014). Top management team psychological characteristics, institutional environment, team processes and performance of companies listed in Naurobi Security exchange. In: K.S. Akpoviroro \& S.O. Owotutu (eds). Impact of external business environment on organizational performance. International Journal of Advance Research and Innovative Ideas in Education. 4(3), 498- 505 .

18. Liebhart, M. and Garcia-Lorenzo, L. (2010). Between planned and emergent change: decision maker's perceptions of managing change in organisations. International Journal of Knowledge, Culture and Change Management, 10(5), 214-225.

19. Methode, K., Osunsan, O.K., Florence, I., Augustine, W., Abiria, P. and Innocent, B. (2019). Effect of OC on Employee Performance among selected Commercial Banks in Bujumbura, Burundi. East African Scholars Journal of Economics, Business and Management. 2(4), 225-234.

20. Muhammad, A., Gatawa, N.M. and Kebbi, H.B. (2013). Impact of information and communication technology on bank performance: A study of selected commercial banks in Nigeria (2001-2011). European Scientific Journal, 9(7), 213-238.

21. Neba, P.N. (2016). Blue Book of Success. In: H. Ebongkeng (eds). OC And Performance: Case study of African Financial Company. Thesis: Centria University of Applied Sciences. 
22. Nicolaidis, C. and Katsaros, K. (2011). Tolerance to change of ambiguity and emotional attitudes in a changing business environment: A case of Greek IT CEOs. Journal of Strategy and Management, 4(1), 44-61.

23. Nwakoby, N.P., Okoye, J.F. and Anugwu, C.C. (2019), Effect of Organizational Culture on Employee Performance in Selected Deposit Money Banks in Enugu State. Journal of Economics and Business, 2(4), 1213- 1225. DOI: 10.31014/aior.1992.02.04.162.

24. Ojo, A.T., (2010). The Nigerian maladapted financial system: Reforming tasks and development dilemma. Yaba Lagos Nigeria: The CIBN Press Limited.

25. Tefera, O. and Mutambara, E. (2014). Effect of OCs on employees' motivation at a Country Club in Kwazulu Natal: from the employees' participation perspectives. African Journal of Hospitality, Tourism and Leisure. 5(1), 1-14.

26. Van de Ven, A.H., \& Poole, M.S. (1995). Explaining Development and Change in Organizations. The Academy of Management Review, 20(3), 510-540. doi:10.2307/258786.

27. Wanza, L. and Nkuraru, J.K. (2016). Influence of Change Management on Employee Performance: A Case of University of Eldoret, Kenya. International Journal of Business and Social Science. 7(4), 190-199.

28. Woods, J.G. (2013). Model of Dialectical Learning. Encyclopedia of Creativity, Invention, Innovation and Entrepreneurship, 1307-1313.

29. Yang, R.S., Zhuo, X.Z. and Yu, H.Y. (2009). Organization theory and management: cases, measurements, and industrial applications. Taipei: Yeh-Yeh.

30. Zikmund, W.G., Babin, J., Carr. J.C \& Griffin, M. (2010).Business Research Methods. $8^{\text {th }}$ Ed. South-Western: Cengage Learning. 